\title{
Equanimity of Risk and Return Relationship between Shariah Index and General Index in India
}

\author{
${ }^{*}$ M. Dharani, P. Natarajan \\ Department of Commerce, Pondicherry University, Puducherry-605014, India \\ *mdharani85@gmail.com
}

\begin{abstract}
The present study empirically examines the risk and return of the Nifty Shariah index and Nifty index during the period $2^{\text {nd }}$ January 2007 to $31^{\text {st }}$ December 2010. The sample period is further divided into bull market period and bear market period based on the movement of the both indices during the study period. The objective of the study is to analyse the performance of the Islamic index and common index and to test whether any significant difference between both indices in India. Based on the previous studies, the present paper employs Risk adjusted measurement such as Sharpe index, Treynor Index and Jensen alpha. The $t$ - test is used to test the mean returns difference between both indices. The study found that Nifty Shariah has been underperformed during the sample and sub sample period. According to ttest, the mean difference between both indices has not been significant which reveals both are consistent. The risk adjusted returns for the both indices reveals that both were underperforming with respect to risk free rate of return. The study has also disclosed the low volatile nature of Nifty Shariah than Nifty index. Finally, the study concludes that Nifty Shariah and Nifty indices in India are performing in a similar manner.
\end{abstract}

Key words: Nifty Shariah, Islamic Finance, Islamic capital Market, Risk adjusted returns, Islamic index.

\section{Introduction}

Over the last few years, the demand for Shariah compliant financial products has increased. Islamic investment obtained its significance in the developed and developing countries after 1990's with the introduction of broad macroeconomic and structural reforms in financial system, the adoption of liberalization policies for trade, capital movements, privatization, and global integration of financial market, and intern they have paved the way for Muslim community to participate in the stock market operations. The stock market operations of the Muslim community are organized by Shariah Advisory Committee (Shariah Supervisory Board) of a country which creates and forms the rules and regulation for investment on the basis of Islamic law for the benefit of 1.5 billion Muslim populations among the 6.3 billion world population.

\section{Shariah Compliance}

Shariah Advisory Committee of the Country provides the guidelines, regulation and protects interest of the Muslim investors who wish to invest on the companies that adheres the Shariah principles. The Shariah principles include

Sector-Based Screens: Business activities related Pork, Alcohol, Gambling, Financials, Advertising and Media (newspapers are allowed, sub-industries are analyzed individually), Pornography, Tobacco, Trading of gold and silver as cash on deferred basis are excluded from the Islamic index. During the selection process, each company's audited annual report is reviewed to ensure that the company is not involved in any non-Shariah compliant activities. Those that are found to be non compliant are screened out. The above industries are not considered Islamic and would not be appropriate for investment for observant Muslims.

Accounting-Based Screens: After removing companies with non-compliant business activities, the rest of the companies are examined for compliance in financial ratios, as certain ratios may violate compliance measurements. There are

1. Debt / Market Value of Equity (12 Month average) < $33 \%$;

2. Accounts Receivables / Market value of Equity (12 Month average) < $49 \%$;

3. (Cash + Interest Bearing Securities) / Market value of Equity (12 Month average) <33\%;

4. In certain cases, revenues from noncompliant activities are permissible, if they comply with the following threshold: (Non-Permissible Income other than Interest Income) / Revenue $<5 \%$ 
On the basis of above principles, Standard \& Poor's and Indian Index service \& product Ltd (IISL) in India have jointly launched two major Shariah indices namely S\&P CNX Nifty Shariah and S\&P CNX 500 Shariah December 2006. Presently, the S\&P CNX Nifty Shariah index includes 38 Shariah compliant companies with the market capitalisation of Rs 5280.42 million, and S\&P CNX 500 Shariah index include 211 Shariah compliant companies out of S\&P 500 companies with the market capitalisation of Rs 6773.11. Dr. Nisar (Director, Shariah Advisory Company) suggests that a number of Shariah-compliant stocks in India are much higher than in Muslim countries put together, thus providing larger scope for Muslim investors. He states that 61 per cent Indian companies are Shariah-compliant against 57 per cent in Malaysia, 51 per cent in Pakistan and a mere 6 per cent in Bahrain. He also says that 335 of 1000 listed firms at National Stock Exchange of India and 237 out of 500 listed at Bombay Stock Exchange are Shariah-compliant. This indicates the favorable sign of Shariah indices to perform well in the future.

Globally, the existing research literature pertaining to Islamic indices is limited. However, Ahmad and Ibrahim (2002); Hakim and Rashidian (2002); Hussein (2005); Albaity and Ahmad (2008) analyses the performance of Islamic indices vis-a-vis conventional stock market indices using stock market data. The studies such as Saharudin et al (2005); Beik and Wardhana (2009) evaluate the volatility and forecasting ability of Islamic indices. These studies are mostly analysed for developed countries. However, the literature on the subject in emerging countries like India is scarce. Therefore, the present study intends to examine the performance of the Islamic index and compare its performance with the general Indian stock market index. Specifically, this paper examines whether the performance of the Islamic index is significantly differ from performance of general index in India. This paper is divided into six sections including the present one. The second section elaborates relevant literature review regarding Shariah index. Third section and fourth section reveal relevant methodology for the study and empirical results respectively. Finally, summary and conclusion present in fifth section in this study.

\section{Review of Literature}

Despite the great need, hardly a very few research work has been undertaken in the area of Islamic finance and investments. Perhaps, this could be attributed to two main barriers: the lack of financial support and the increasing confidentiality of the data required for analysis. Islamic banks and financial institutions face very high competition both among themselves and with other conventional financial institutions. Along with the high competition, Islamic financial institutions don't seem to see any significant reward for the heavy outlays required for research. For this, only a few studies have tackled the issue of Shariah ruling impact on the performance of the Islamic stock index.

Ahmad and Ibrahim (2002) compare the risk and return performance of Kuala Lumpur Shariah Index (KLSI) with Kuala Lumpur Composite index (KLCI) during the period 1999 to 2002. The sample period of the study is divided into growing period, decline period and overall period. They employ relative return technique, Standard deviation, risk adjusted performance measurement and two sample $\mathrm{t}$ - test as a tool for performance measures of the both indices. The study finds that KLSI underperforms during overall period and decline period but it overperform in growing period. Finally, they find that there is no significant difference in performance of both indices during the sample period. Hakim and Rashidian (2004) analyses the risk and return of Dow Jone Islamic Stock Market Indices (DJIM) from 1999 to 2002. They initially compare DJIM index, Wilshire 5000 stock market index using continuously compound return and annualized standard deviation with the 91 days $\mathrm{T}$ bill rate and its standard deviation. The study finds that the three month $\mathrm{T}$ bill returns dominate both the Islamic Index and the Wilshire 5000 stock market index. However, return and risk of the Islamic index is less than the Wilshire 5000. The study also examines the long run and short run relationship existing among the variables using unit root test, co integration and causality test. The study finds that $\mathrm{T}$ bill returns, Islamic index returns and Wilshire 5000 returns are not co- integrated. Hussein (2004) compares the performance of ethical investment with their unscreened benchmarks. The study empirically tests whether returns of FTSE Global Islamic Index are significantly different from their index counterpart (FTSE All- World Index). The sample period is divided into two sub-periods, bull period (July 1996 - March 2000) and bear period (April 2000-August 2003). A comparison of the raw and risk-adjusted performance show that the Islamic index performs as well as the FTSE All-World index over the entire period. On the other hand, the Islamic index yields statistically significant positive abnormal returns in the bull market period, although it underperforms the counterpart index in the bear market period. In general, the results show that the 
application of ethical screening does not have an adverse effect on the FTSE Global Islamic Index performance.

Hussein (2005) tests whether monthly returns of Financial time stock Exchange (FTSE) Global Islamic index and Dow Jone Islamic Market Index are significantly different from their common index for the period January 1996 to December 2004. The sample period is divided into bull market and bear market. The study employs Capital Asset pricing model, Risk adjusted performance measurement, $t$-test, Wilcoxon Signed test, buy and hold return method and cumulative return method for examine long run and short run relationship between indices. In short run period, Islamic indices statistically overperfom during whole period and second bull market period. In long run, Islamic indices overperfom during entire period and second bull market period. Finally, the study finds that there is a similar performance between indices. Girard and Hassan (2006) examined the performance of seven indexes chosen from the Dow Jones Islamic Market Index (DJIM) vis-à-vis their non-Islamic counterparts using a variety of measures such as Sharpe, Treynor, Jenson and Fama's selectivity, net selectivity and diversification. Second, they examine the persistence of performance using Carhart's (1997) four factor pricing models. Third, the study uses co-integration to examine how the Islamic indexes compare to their non-Islamic counterparts. The sample period is from January 1996 to November 2005 (118 data points). It is further broken down into two sub-periods - i.e, January 1996 to November 2000 (59 data points) and December 2000 to November 2005 (59 data points). The study finds no difference between Islamic and non-Islamic indexes. The Dow Jones Islamic indexes outperform their conventional counterparts from 1996 to 2000 and underperform them from 2001 to 2005. Overall, similar reward to risk and diversification benefits exist for both the Islamic and conventional indexes. Rahman and Wajdi (2006) tried to examine whether Shariah-compliant firms pay higher dividend than non-Shariah-compliant firms during end of 2004. Further, they also attempted to provide empirical evidence on whether Shariah and non-Shariah compliant firms have different level of agency cost. The study uses Cost of sales, Sales and general administration expense, Annual sales, and Dividend per share as study variables. The result of the study shows that Shariah-compliant firms pay higher dividend to their shareholders than non-Shariah compliant firms. Further, this study finds that Shariah-compliant firms facing less agency cost than nonShariah compliant firm.

Yusof and Majid (2007) attempt to explore the extent to which the conditional volatilities of both conventional and Islamic stock markets in Malaysia are related to the conditional volatility of monetary policy variables. Among the monetary policy variables tested in the study are the narrow money supply (M1), the broad money supply (M2), interest rates (TBR), exchange rate (MYR), and Industrial Production Index (IPI), while the Kuala Lumpur Composite Index (KLCI) and Rashid Hussain Berhad Islamic Index (RHBII) are used as measures for conventional and Islamic stock markets, respectively. In order to capture the international influence on both stock markets, the volatility in the U.S. monetary policy variable measured by the Federal Funds Rate (FFR) is incorporated into the study. Generalized Autoregressive Conditional Heteroskedasticity (GARCH)-M, GARCH $(1,1)$ framework together with Vector Autoregressive (VAR) analysis are employed for the monthly data starting from January 1992 to December 2000 in this study. The study finds that interest rate volatility affects the conventional stock market volatility but not the Islamic stock market volatility. This highlights the tenet of Islamic principles that the interest rate is not a significant variable in explaining stock market volatility. The results provide further support that stabilizing interest rate would have insignificant impact on the volatility of the Islamic stock markets.

Albaity and Ahmad (2008) investigate the performance and relationship between KLSI and KLCE over the period of April 1999 to December 2005 in Malaysia. The study applies risk adjusted performance measurement, causality and Johansen co integration test. They find that there is an insignificant return difference and long run bidirectional relationship between both indices. Sadegi (2008) investigates the impact of the introduction of Bursa Malaysia Islamic index on the financial performance and liquidity of the screening securities involved in the Islamic index in Malaysia. The study uses event study methodology to estimate mean cumulative returns of the Shariah compliant stocks in the days surrounding the event and also investigate the changes in liquidity using trade volume and bid ask spread surrounding the event days as liquidity proxies. The study finds that the introduction of the Shariah index has positive and strong impact on the financial performance of the Shariah compliant stocks. Mohd Dali et al. (2008) try to identify the performing and non-performing companies by using multiple discriminant analysis (MDA) and multiple regression and the ratios that could distinguish between the performing and the under-performing companies. First, the study applied the Jensen technique to classify the Shariah 
compliance companies into performing and non-performing. Then, the results from the Jensen technique with 20 financial ratios are applied to MDA in order to establish models that are used to identify nonperforming and performing companies. The results show that the growth turnover ratio is the only ratio that could discriminate between the performing and non-performing companies in the plantation industry.

Biek and Wardhana (2009) find the relationship between Jakarta Islamic Index and other selected markets indices during the period of January 2006 to December 2008. The study apply Unit root test, Co integration and Vector auto regressive model (VAR) to examine the long run relationship among the selected sample indices in the study. The results show that there is no long run relationship between Jakarta Islamic Index and other selected Market index during the study period. Seng et al. (2009) empirically analysis the performance of Shariha-Compliant Indices (SCIs) by evaluating the performance of a number of SCIs, in comparison to similar mainstream indices, as well as in comparison to other ethical funds. Furthermore, the paper test for co-integration among the SCIs and the mainstream ones to establish whether there is any scope for diversification. The main findings are that SCIs offer an opportunity for portfolio diversification with mainstream indices and other ethical funds within the UK. Dharani and Natarajan (2011) compare the risk and return of the S\&P CNX Nifty Shariah index and S\&P CNX Nifty index at day wise, moth wise and quarter wise during $2^{\text {nd }}$ January 2007 to $31^{\text {st }}$ December 2010. The study finds that there is a significance return difference between both indices during third quarter in India. Finally, the study finds that Ramalan effect prevailing in the Shariah index during third quarter of the study period. Thus, the review of literature clearly states that Islamic investment has been flourishing in all over the world since 1970. But no such comprehensive study has been undertaken in India. So this study first explain theoretical and conceptual framework regarding Islamic finance. Based on the earlier research studies, this study attempts to investigate the performance of Shariah index in India.

\section{Methodology}

This empirical study has been undertaken mainly on secondary daily time series data such as daily closing value of the S\&P CNX Nifty Shariah index and S\&P CNX Nifty index from $2^{\text {nd }}$ January 2007 to $31^{\text {st }}$ December 2010. The closing values of the both indices were collected from the Indices segment of the NSE. Similarly, the three month Mumbai interbank offer rate obtained from the Debt segment of the NSE, which was used as proxy for risk free rate return.

First, the researchers have calculated the raw returns and risk adjusted returns for S\&P CNX Nifty Shariah and S\&P CNX Nifty indices and then researchers classified the computed returns as first bull market period, bear market period and second bull market period to check whether their performance changes during stock market crises. The significant differences between raw returns of both S\&P CNX Nifty Shariah and S\&P CNX Nifty are examined by employing 'two sample mean $t$ test'. Further, this study has estimated the simple returns by taking into the daily return as today's index value minus yesterday's index value and divided it by yesterday's index value.

$$
R_{t}=\left(P_{t}-P_{t-1}\right) / P_{t-1}
$$

Where, $R_{t}$ is the return at time $t, P_{t}$ is the index value at time $t$ (today's index value) and $P_{t-1}$ is the index value at time t-1 (yesterday's index value).

The risk adjusted return as a performance measure was estimated using the Sharpe index ratio (1966), Treynor ratio (1965) and Jenson ratio (1968). The Sharpe index ratio measures the performance of securities indices. This indicates the amount of excess return of the portfolio over the risk free rate in a given period per unit of risk. The same approach was adopted by Albaity and Ahmad (2008) for analysing the performance of Shariah index of Bursa Malaysia. The present study also employed the same measure in Indian context for analyzing the performance of S\&P CNX Nifty Shariah and S\&P CNX Nifty. The Sharpe Index (SI) is as follows:

$$
\mathrm{SI}_{\mathrm{it}}=\left[\left(\mathrm{AR}_{\mathrm{it}}-\mathrm{ARFR}\right)\right] / \sigma_{\mathrm{i}}
$$

Where,

$\mathrm{AR}_{\mathrm{i}} \quad$ is daily average return for the Index over the period

ARFR is daily average of the risk free rate

$\sigma_{i} \quad$ is Standard deviaton of Index return 
Treynor (1965) developed the Treynor index performance measure to find the porfolio performance including risk which is associated with the general market fluctulations. This performanc measure differ from sharpe ratio because it uses beta or systamatic risk, whereas sharpe ratio use standard deviation of returns as a measure of total risk in examining the porfolio performance. However, higher Treynor ratio indicated superior performance of indices and vice versa. The Treynor ratio for the selected indices is computed as:

$$
\mathrm{T}_{\mathrm{it}}=\left(\mathrm{AR}_{\mathrm{it}}-\mathrm{ARFR}\right) / \beta
$$

Where, $T_{i t}$ is the Treynor index, a relative measure and compare to the market assuming beta as $1 . \mathrm{AR}_{\mathrm{it}}$ is the average return of the index and ARFR is the average risk free rate of the return. $\beta$ is the beta co efficient computed using market model as:

$$
\mathrm{R}_{\mathrm{it}}=\alpha_{\mathrm{it}}+\beta_{\mathrm{i}} \mathrm{R}_{\mathrm{m}, \mathrm{t}}+\varepsilon_{\mathrm{it}}
$$

Where, $R_{i t}$ and $R_{m, t}$ represent the return of the S\&P CNX Nifty Shariah and S\&P CNX Nifty index respectively, and $\varepsilon_{i t}$ is the residuals of regression. S\&P CNX Nifty is considering as a benchmark index for S\&P CNX Nifty Shariah.

Jensen (1968) introduced Capital Asset Pricing Model (CAPM) based portfolio performance measure to examine the excess return provided by funds called as Jensen Alpha Index Performance measure. It represents the average returns on a portfolio over and above the estimated return using CAPM, to the given portfolio beta and average market return. The Alpha in the model represents the average portfolio return adjusted for risk. The portfolio Alpha is expressed as:

$$
\alpha=\mathrm{AR}_{\mathrm{it}}-\left[\mathrm{ARFR}+\beta_{\mathrm{i}}\left(\mathrm{R}_{\mathrm{m}, \mathrm{t}}-\mathrm{ARFR}\right)\right.
$$

Where, $\alpha_{i}, A R_{i t}, A R F R_{i t}$ and $\beta_{i}$ are as defined above. The positive AJAI indicate the superior performance and the negative AJAI indicate the inferior performance of the portfolio index.

\section{Empirical Results and Discussion}

\section{Graphical Analysis}

The first part of the study represents Nifty Shariah price movement in graphical manner. The chart 1 clearly discloses the movement of the Shariah index during bull market period and bear market period during the study period.

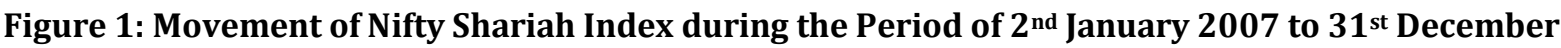
2010.

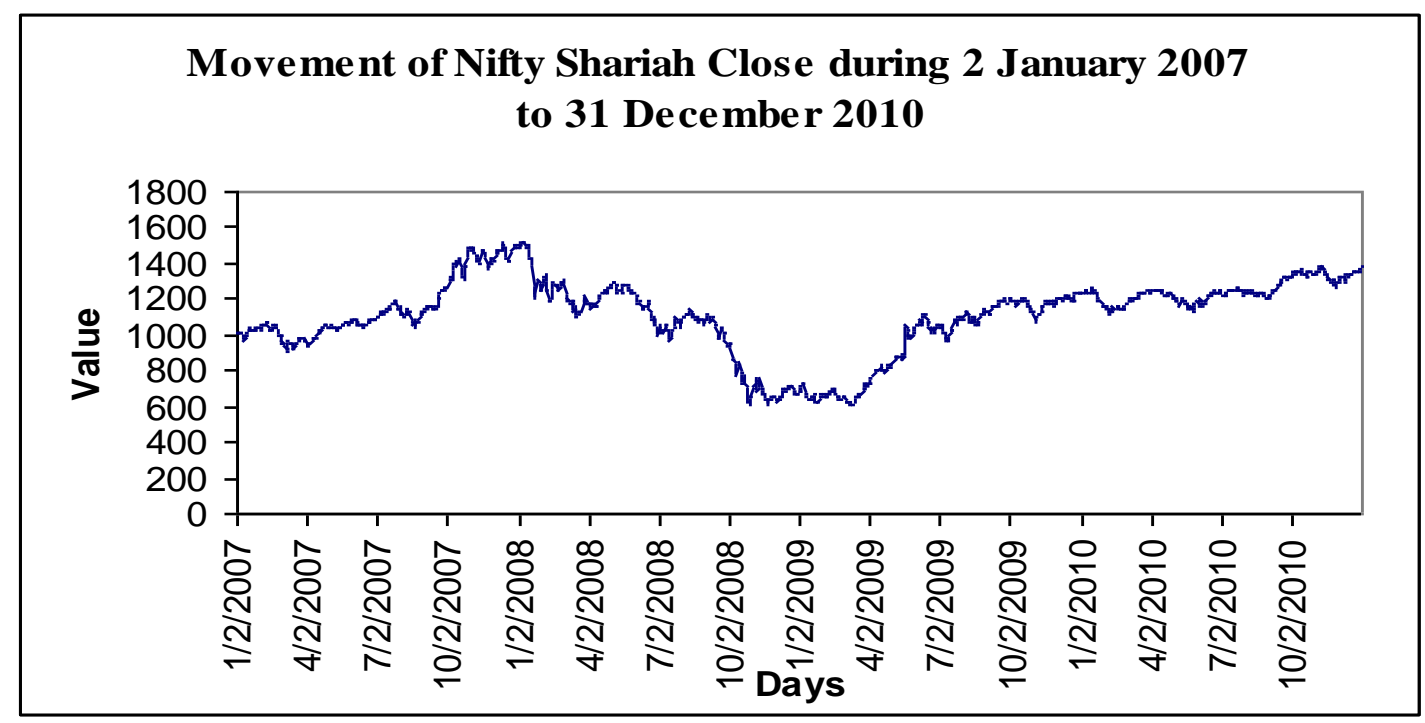


Figure 2: Movement of Nifty Shariah Index during first Bull Market Period from 2nd January 2007 to $14^{\text {th }}$ January 2008.

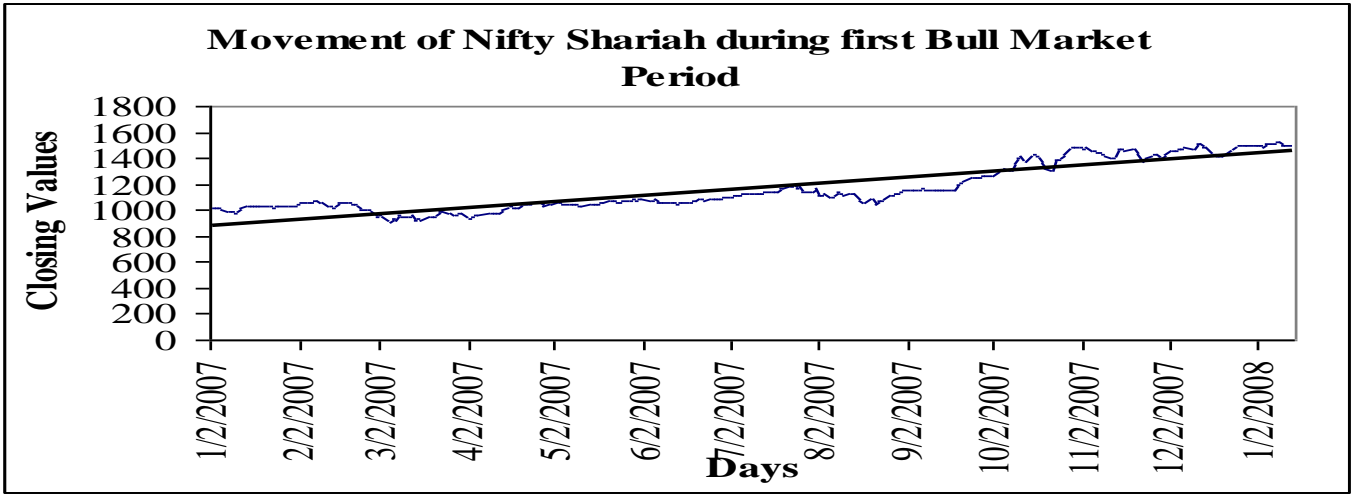

Figure 3: Movement of Nifty Shariah Index during Bear Market Period from $15^{\text {th }}$ January 2008 to $9^{\text {th }}$ March 2009

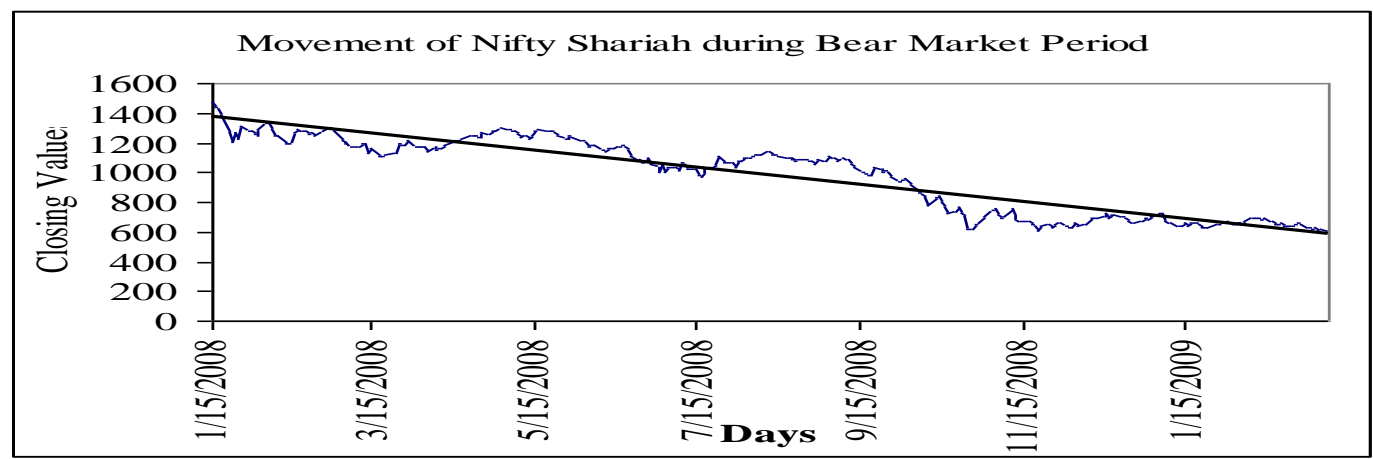

Figure 4: Movement of Nifty Shariah Index during second Bull Market Period from $12^{\text {th }}$ march 2009 to 31 ${ }^{\text {st }}$ December 2010.

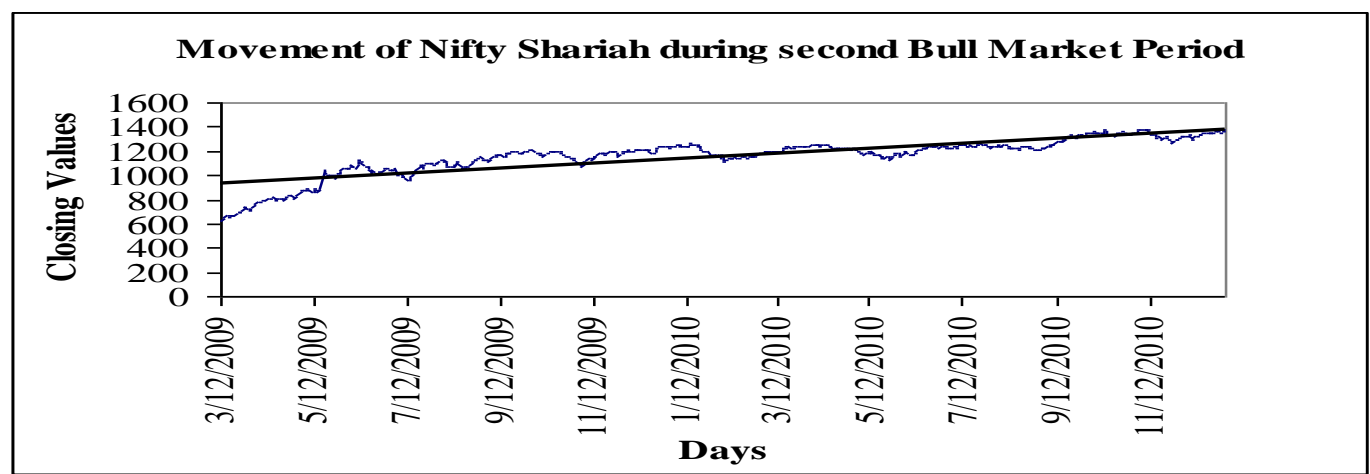

Figure 5: Daily Returns of the Nifty Shariah Index during period $2^{\text {nd }}$ January 2007 to $31^{\text {st }}$ December 2010

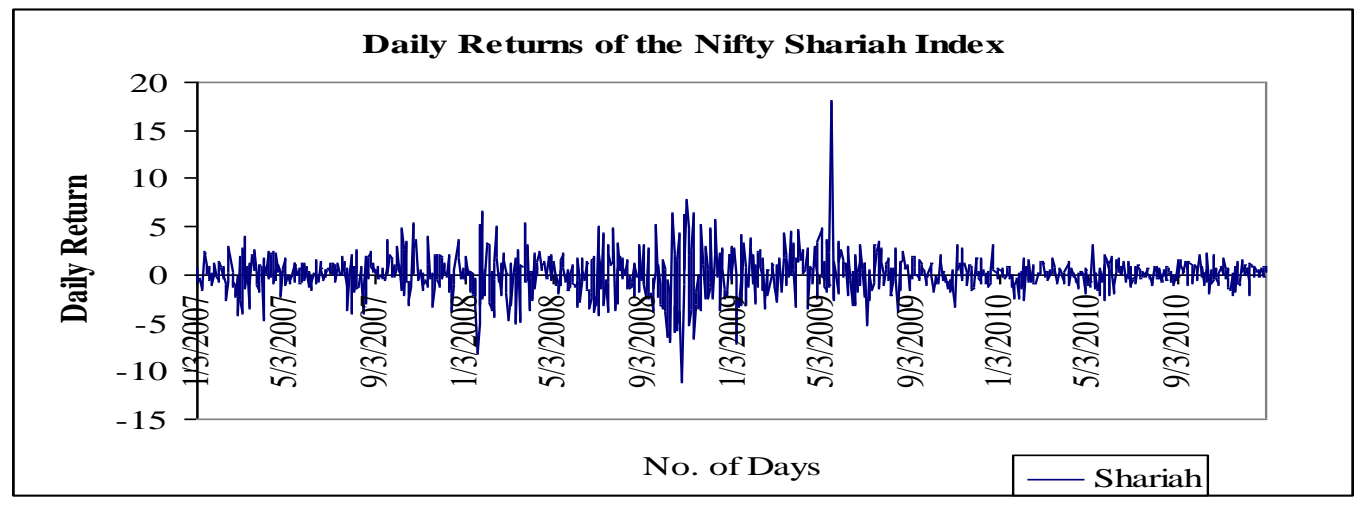

Complied from the daily closing value of the Nifty Shariah Index 


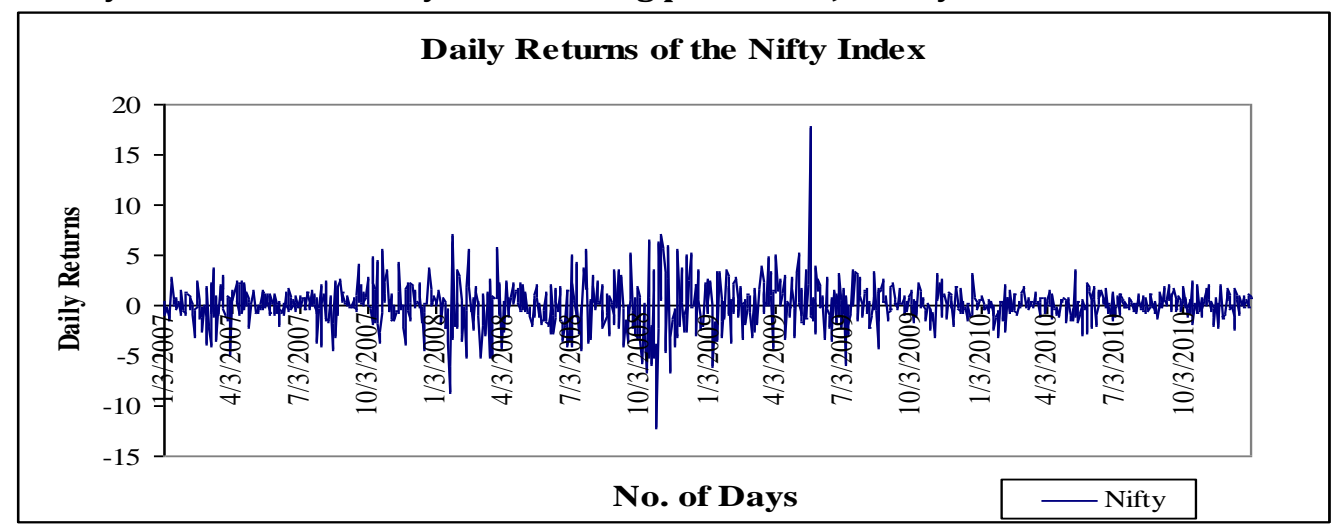

The Figure 1 reveals that the movement of the Nifty Shariah Index for overall period. The movement of the index is increasing from $2^{\text {nd }}$ January 2007 to $14^{\text {th }}$ January 2008. It is called as first bull market period during study period and it is shown in the Figure number 2. From 15 th January 2008 to $9^{\text {th }}$ March 2009, the movement of the Nifty Shariah is coming down. This period represents bear market period and it is declared in Figure number 3. Again, market is growing from 12 th march 2009 to 31 ${ }^{\text {st }}$ December 2010 during the study period. Figure 4 discloses the second bull market period in the study.

\section{Descriptive Statistics}

This part of the empirical study discloses the descriptive statistics of the Nifty Shariah and Nifty index for sample period and sub sample period. In this section, the study tests the following hypothesis.

$\mathrm{H}_{0}=\quad$ Returns of the Nifty Shariah and Nifty are normally distributed during overall period, bull market period and bear market period.

Table 1: Descriptive Statistics for S\&P CNX Nifty Shariah and S\&P CNX Nifty Returns during overall, first bull market, bear market and second bull market period.

\begin{tabular}{|c|c|c|c|c|c|c|c|}
\hline Indices & Mean & SD & Skw & Kurt & Jar-B & $\mathbf{P}$ & Obs \\
\hline \multicolumn{8}{|c|}{ Overall period from 2 $2^{\text {nd }}$ January 2007 to $31^{\text {st }}$ December 2010} \\
\hline Shariah & 0.0509 & 1.976 & 0.487 & 12.04 & $3389 *$ & 0.00 & 984 \\
\hline Nifty & 0.063 & 2.019 & 0.354 & 11.18 & $2767^{*}$ & 0.00 & 984 \\
\hline \multicolumn{8}{|c|}{ First bull market period from $2^{\text {nd }}$ January 2007 to $14^{\text {th }}$ January 2008} \\
\hline Shariah & 0.164 & 1.54 & -0.101 & 4.35 & $20.14^{*}$ & 0.00 & 258 \\
\hline Nifty & 0.182 & 1.58 & -0.168 & 4.56 & $27.54^{*}$ & 0.00 & 258 \\
\hline \multicolumn{8}{|c|}{ Bear Market Period from $15^{\text {th }}$ January 2008 to $9^{\text {th }}$ March 2009} \\
\hline Shariah & -0.278 & 2.73 & -0.106 & 3.91 & $10.08^{*}$ & 0.006 & 277 \\
\hline Nifty & -0.271 & 2.77 & -0.144 & 4.11 & $15.16^{*}$ & 0.00 & 277 \\
\hline \multicolumn{8}{|c|}{ Second Bull Market Period from $12^{\text {th }}$ March 2009 to 31 ${ }^{\text {st }}$ December 2010} \\
\hline Shariah & 0.191 & 1.58 & 3.24 & 38.68 & $24506^{*}$ & 0.00 & 447 \\
\hline Nifty & 0.204 & 1.63 & 2.74 & 32.47 & $16731^{*}$ & 0.00 & 447 \\
\hline
\end{tabular}

Sources: complied from indices values disclosure of NSE, Note: significant at 1\% level

The table 1 provides more details on the property of the daily returns of the both Nifty Shariah and Nifty indices during overall period, first bull market period, bear market period and second bull market period. The normality test suggests the neither of the returns is normally distributed during the selected sample and sub sample period. The Jarque- Bera (JB) normality test is significant at $1 \%$ level suggesting that the null hypothesis of the normality of the data should be rejected, and implying that series are not normally distributed. Both indices are positively skewed during overall period and second bull market period and negatively skewed during first bull market period and bear market period. This indicates that the distribution has a right tail in the period of overall and second bull market and left tail in the period of first bull market and bear market. The kurtosis values of the Nifty Shariah and Nifty indices are greater than 3 for all sample period. This value points out that the distributions of the both indices are leptokurtic during sample period and sub sample period. The mean and standard deviation of daily returns of the Nifty Shariah index during sample period and sub sample period is less than the daily returns of the Nifty 
index. This indicates that the returns of the Nifty are slightly more volatile then the returns of the Nifty Shariah. The other words, the Nifty Shariah index is less risky than the Nifty index in India.

\section{Difference in Mean}

The daily mean returns of the Nifty Shariah is lower than the daily mean returns of the Nifty during sample and sub sample period. In this part, the study tests whether the mean difference between indices during the sample and sub sample period is statistically significant or not. Hence, this study formulates the following null hypothesis.

$\mathrm{H}_{0}=\quad$ There is no difference between mean returns of the both indices during overall period, bull market period and bear market period.

Table 2: t-test for Mean differences between Returns of Nifty and Nifty Shariah during overall, first bull market, bear market and second bull market period.

\begin{tabular}{lllll}
\hline Period & Mean Difference & t-value & p-value & Correlation \\
\hline Overall Period & 0.0121 & 0.139 & 0.889 & 0.984 \\
First Bull Market & 0.018 & 0.134 & 0.893 & 0.981 \\
Bear Market & 0.549 & 0.033 & 0.974 & 0.988 \\
Second Bull Market & 0.013 & 0.121 & 0.904 & 0.977 \\
\hline
\end{tabular}

Sources: complied from indices values disclosure of NSE

According the table 2, $\mathrm{t}$ value and $\mathrm{p}$ value indicate that there is no difference between the mean returns of the both indices during sample and sub sample period. Hence, this study supports the null hypothesis. The correlation between the returns of the Nifty Shariah and Nifty is positive and highly strong. This indicates that there is a strong linear relationship between returns of the both indices in India. This is consistent with the results of Ahamad and Ibrahim (2002), Statman (2000), Hussein and Omran (2005), and Albaity and Ahamad (2008) that the returns of ethical investments are not significantly different from those of conventional investment.

\section{Positive and Negative Returns Analysis}

This section deals with number of days Nifty Shariah and Nifty provided positive and negative returns during the overall sample and sub sample period. The results are provided in table 3.

Table 3: Number of days positive and negative daily returns during overall, first bull market, bear market and second bull market period.

\begin{tabular}{lllll}
\hline \multirow{2}{*}{ Study Periods } & \multicolumn{2}{c}{ Nifty Shariah } & \multicolumn{2}{c}{ Nifty } \\
\cline { 2 - 5 } Overall Period & Positive & Negative & Positive & Negative \\
First Bull Market Period & $510(51.8)$ & $474(48.2)$ & $528(53.7)$ & $456(46.3)$ \\
Bear Market Period & $144(55.8)$ & $114(44.2)$ & $148(57.4)$ & $110(42.6)$ \\
Second Bull Market Period & $126(45.5)$ & $151(54.5)$ & $132(47.7)$ & $145(52.3)$ \\
\hline
\end{tabular}

Sources: compiled from indices values disclosure of NSE, Note: parenthesis indicates the percentage

The table explains that the Nifty Shariah index is provided 510 days positive returns and 474 days negative returns while Nifty index is provided 528 days positive returns and 456 days negative returns during the overall study period. In bear market period, 45.5 percent of the days provide positive returns and 54.5 percent of the days yield negative returns for Nifty Shariah whereas 47.7 percent positive returns and 52.3 percent negative returns for Nifty index. During the first and second bull market period, both indices are provided more than 50 percent positive returns. This result indicates that on an average both indices are provided more number of positive returns in bull market period and more number of negative returns in bear market period.

\section{Risk Adjusted Performance}

The risk adjusted returns are computed for Nifty Shariah and Nifty indices during the sample and sub sample study periods. The Nifty index is taken as a benchmark index to the Nifty Shariah index. And also 
three month Mumbai Inter bank Offer Rate (MIBOR) is considered as a proxy for risk free rate of returns. The results of the risk adjusted returns are presented in the table 4.

Table 4: Risk Adjusted Performance and Beat of Nifty and Nifty Shariah during overall, first bull market, bear market and second bull market period

\begin{tabular}{|c|c|c|c|c|}
\hline Index & Sharpe ratio & Treynor index & Jensen alpha & Beta \\
\hline \multicolumn{5}{|c|}{ Overall period from 2nd January 2007 to 31st December 2010} \\
\hline Nifty Shariah & -0.0388 & -0.0797 & -0.00296 & 0.963 \\
\hline Nifty & -0.0379 & -0.0766 & & \\
\hline \multicolumn{5}{|c|}{ First bull market period from 2nd January 2007 to 14th January 2008} \\
\hline Nifty Shariah & -0.0579 & -0.0935 & -0.00019 & 0.955 \\
\hline Nifty & -0.0563 & -0.0891 & & \\
\hline \multicolumn{5}{|c|}{ Bear Market Period from 15th January 2008 to 9th March 2009} \\
\hline Nifty Shariah & -0.0363 & -0.102 & -0.0643 & 0.972 \\
\hline Nifty & -0.0357 & -0.099 & & \\
\hline \multicolumn{5}{|c|}{ Second Bull Market Period from 12th March 2009 to 31st December 2010} \\
\hline Nifty Shariah & -0.0353 & -0.0588 & -0.0234 & 0.949 \\
\hline Nifty & -0.0342 & -0.0557 & & \\
\hline
\end{tabular}

Sources: complied from indices values disclosure of NSE

The table 4 discloses the risk adjusted returns for Nifty Shariah and Nifty by employing three different measurements such as Sharpe index, Tryenor index and Jensen alpha. The Nifty index is considered as a benchmark index for measurement purpose. According to the Sharpe index and Treynor index, the Nifty Shariah is provided less risk adjusted returns than the Nifty index during sample and sub sample period. The Jensen measure for the Nifty Shariah is negative for all the period and indicates that Islamic index is underperformed compared with benchmark index i.e. Nifty index. The overall results represent that the Islamic index or Shariah index in India is less risky than the common index during the study period.

\section{Summary and Conclusion}

The present study empirically examined the risk and return of the Nifty Shariah index and Nifty index during the period $2^{\text {nd }}$ January 2007 to $31^{\text {st }}$ December 2010. The sample period has been further divided into bull market period and bear market period based on the movement of the both indices during the study period. The objective of the study is to analyse the performance of the Islamic index and common index and to test whether any significant difference between the both indices in India. Based on the previous studies, the present paper employs riks adjusted measurement such as Sharpe index, Treynor Index and Jensen alpha. The t- test has been used to test the mean returns difference between both indices. The study finds that Nifty Shariah has underperformed during the sample and sub sample period. According to t-test, the mean difference between both indices has not been significant which reveals both are consistent. The risk adjusted returns for the both indices reveals that both were underperforming with respect to risk free rate of return. The study has also disclosed the low volatile nature of Nifty Shariah than Nifty index. Finally, the study concludes that Nifty Shariah and Nifty indices in India are similar performance in term of returns.

\section{References}

Ahmad \& Ibrahim. (2002). A Study of Performance of the KLSE Shariah Index, Malaysian Management Journal, 6 (1\&2): 25-34.

Albaity, M. and Ahmad, R. (2008). Performance of Shariah and Composite Indices: Evidence from Bursa Malaysia. Asian Academy of Management Journal of Accounting and Finance. 4(1): 23-43.

Beik, S. I. and Wardhana, W. (2009). The Relationship between Jakarta Islamic Index and Other Selected Markets: Evidence from Impulse Response Function. Persatuan Pelajar Indonesia International Islamic University Malaysia. ppi-iium.org/.../The\%20Relationship\%20between \%20JII\% 20\&\% 20US.pdf.

Carhart, M. M., (1997). On persistence in mutual fund performance. Journal of Finance 52: 57-82. 
Dharani M., \& Natarajan, P. (2011). Seasonal Anomalies between S\&P CNX Nifty Shariah Index and S\&P CNX Nifty Index in India. Journal of Social and Development Sciences, 1(3): 101-108.

Girard, E. \& Hassan, K. M. (2006). Faith-Based Ethical Investing: The Case of Dow Jones Islamic Indexes. Available in papers.ssrn.com/sol3/papers.cfm? abstract_id= 1808853.

Hakim. S. \& Rashidian, M. (2002). Risk and Return of the Islamic Stock Market. Paper presented at the presentation to Economic Research Forum Annual Meetings, Sharjah, UAE.

Hakim, S. \& Manochehr, R. (2004). Risk \& Return of Islamic Stock Market Indexes. Paper presented at the International Seminar of Non-bank Financial Institutions: Islamic Alternatives, Kuala Lumpur, Malaysia.

Hakim, S. \& Rashidian, M. (2004). How costly is investor's compliance to Shariah? Paper presented at the 11th Economic Research Forum Annual Conference in Sharjah, U.A.E. on December 14-16, Beirut, Lebanon.

Jensen, M. C. (1968). The Performance of Mutual Funds in the Period 1945-1964. Journal of Finance, 23: 389-419.

Hussein, A. K. (2004). Ethical Investment: Empirical Evidence from FTSE Islamic Index. Islamic Economic Studies, 12(1): 21-40.

Hussein, A. K. (2005). Islamic Investment: Evidence From Dow Jones and FTSE Indices, Working paper, Islamic Business Research Centre, Norway.

Mohd Dali, N. R. S. B., Mudasir, H. H. and Hamid, S. A. (2008). Performance of Shariah compliance companies in the plantation industry. International Journal of Islamic and Middle Eastern Finance and Management. 1(2): 166-178.

Rahman, F. A. and Wajdi, F. M. (2006). Dividend Signaling Hypothesis and Agency Cost: An Investigation on Shariah and Non Shariah Compliant Firms in Kuala Lumpur. Shariah Index Empirika, 19(1): 19.

Sadeghi, M. (2008). Financial Performance of Shariah-Compliant Investment: Evidence from Malaysian Stock Market. International Research Journal of Finance and Economics, 20: 15-26.

Saharudin S., Hussein A., Abu s. Adu B. and Hasniza Mohd T. (2005). Volatility Trends of Shariah Index Returns and Kuala Lumpur Composite Index. Journal Shariah, 13(2): 65-91.

Sharpe, W. F. (1964). Capital Asset Pricing: A Theory of Market Equilibrium under Conditions of Risk. Journal of Finance, 19(September): 425-42.

Seng, K., Gianluigi. G. and Jason, L. (2009). Performance of Shariah-Compliant Indices in London and NY Stock Markets and their potential for diversification. International Journal of Monetary Economics and Finance, 2(3/4): 398-408.

Treynor, J.L. (1965) How to Rate Management of Investment Funds. Harvard Business Review, vol. 43, January-February, pp. 63-75. www.kantakji.com/fiqh/Files/ Markets/ Khaled_A_Hussein_1.pdf

Yusof, M. R. and Abd. Majid, S. M. (2007). Stock Market Volatility Transmission in Malaysia: Islamic Versus Conventional Stock Market J. KAU: Islamic Econ. 20(2): 17-35. 